\title{
PROSES PERANCANGAN INOVASI FORM KAPALKU GUNA PENDATAAN KEPUASAN PENUMPANG KAPAL FERRY DARI PELABUHAN TANJUNGPINANG
}

\author{
Deny Nusyirwan ${ }^{1 *}$, Muhammad Bayu Purnama ${ }^{2}$, Prasetya Perwira Putra Perdana ${ }^{3}$ \\ ${ }^{1,2,3}$ Program Studi Teknik Elektro, Fakultas Teknik, Universitas Maritim Raja Ali Haji (UMRAH) \\ Jl. Politeknik Senggarang, Tanjungpinang 29100 \\ Email: denynusyirwan@umrah.ac.id
}

\begin{abstract}
Passenger satisfaction is one of the important roles in companies and transportation services that are committed to social innovation. Maritime territories are areas which are mostly waters, in maritime areas, transportation services lead to the sea. The sea is a means of creating sea transportation called ships. The ship became one of the forms of transportation sophistication from the past until now. Ships are also one of the most reliable transportation in the maritime area, but at this time the problem arises because of the large number of ships and ship transportation services that are the livelihoods of the maritime community. That way the comparison between ships and ships is greatly improved, especially it can be concluded from the number of passengers and ship passenger charts. Today passenger satisfaction is given priority, especially in supporting facilities such as comfortable seats, conducive air conditioning, and good service. But the research method used in this innovation is the observation method which includes collecting data on user testing and user experience at that stage. The Kapalku Form is one of the innovations that applies passenger satisfaction data collection based on information system, the way it works is to press the selection button according to the colors provided, namely red, yellow, and green in each passenger seat. The incoming data will be calculated according to how many passengers press the button. Red means not satisfied, green means satisfied, and yellow means very satisfied. That way, data obtained through the sensitivity of the button will be sent via Bluetooth to Android. Furthermore, the data listed on android will appear on the monitor that can be accessed via Google form. The results of this study can be seen from the Google form data graph which is the android data transition through the sensitivity of the button, so that it can easily find out the level of service satisfaction on the ship in accordance with the criteria and improving the quality of the ship.
\end{abstract}

Keywords: android, google form, ship, passenger satisfaction, button

\begin{abstract}
Abstrak. Kepuasan penumpang menjadi salah satu peran penting didalam perusahaan maupun jasa transportasi yang berdominan kepada inovasi sosial. Wilayah maritim adalah wilayah yang sebagaian besarnya adalah perairan, didalam wilayah maritim jasa transportasi mengarah kepada laut. Laut menjadi sarana terciptanya transportasi laut yang dinamakan kapal. Kapal menjadi salah satu bentuk kecanggihan transportasi dari dahulu hingga sekarang. Kapal juga menjadi salah satu transportasi yang dapat diandalkan tertuama di wilayah maritim, namun pada saat ini masalah muncul karena banyaknya kapal dan jasa transportasi kapal yang menjadi mata pencaharian masyarakat maritim. Dengan begitu perbandingan antara kapal dengan kapal sangat meningkat, tertutama bisa disimpulkan dari banyaknya penumpang dan grafik penumpang kapal. Dimasa sekarang kepuasan penumpang sangat diutamakan, terutama pada fasilitas yang mendukung seperti kursi yang nyaman, pendingin udara yang kondunsif, dan pelayanan yang baik. Namun metode penelitian yan digunakan pada inovasi ini adalah metode observasi yang mencakup pada pengambilan data pada user testing dan user experience pada tahapnya. Form Kapalku menjadi salah satu inovasi yang menerapkan pendataan kepuasan penumpang berbasis sistem informasi yang cara kerjanya adalah menekan tombol pilihan sesuai warna yang disediakan yaitu merah, kuning, dan hijau di masing-masing kursi penumpang. Data yang masuk akan di hitung sesuai dengan seberpaa banyak penumpang menekan tombol tersebut. Merah artinya tidak puas, hijau artinya puas, dan kuning artinya sangat puas. Dengan begitu, data yang didapatkan melalui kepekaan tombol akan dikirim melalui Bluetooth ke android. Selanjutnya data yang tertera di android akan tampil pada monitor yang dapat diakses melalui google form. Hasil dari penelitian ini dapat dilihat dari grafik data google form yang merupakan transisi data android melalui kepekaan tombol, sehingga dapat dengan mudah mengetahui tingkat kepuasan pelayanan pada kapal sesuai dengan kiteria dan peningkatan mutu kualitas kapal tersebut.
\end{abstract}

Kata kunci : android, google form, kapal, kepuasan penumpang, tombol 


\section{PENDAHULUAN}

Penggunaaan kuesioner untuk mendapatkan informasi kepuasan pelanggan terhadap produk maupun pelayanan yang diberikan tentunya akan verpengaruh terhadap biaya dan waktu sehingga juga akan mempengaruhi kinerja dari perorangan maupun kelompok yang bertugas untuk mengumpulkan informasi tersebut. Dengan kemajuan teknologi informasi di era revolusi industri 4.0 saat ini, dilakukan transformasi ke arah digital sehingga kuesioner dapat dilakukan secara online dan informasi yang dihasilkan juga bersifat realtime (Saputra dan Nugroho, 2017). Selain hal tersebut, pengguna juga dapat melakukan pengisian tanpa ada batasan waktu dan ruang (Kurniadi dan Islami, 2018)

Kepuasan penumpang menjadi salah satu peran penting didalam perusahaan maupun jasa transportasi yang berdominan kepada inovasi sosial. Wilayah maritim adalah wilayah yang sebagaian besarnya adalah perairan, didalam wilayah maritim jasa transportasi mengarah kepada laut. Laut menjadi sarana terciptanya transportasi laut yang dinamakan kapal. Kapal menjadi salah satu bentuk kecanggihan transportasi dari dahulu hingga sekarang. Kapal juga menjadi salah satu transportasi yang dapat diandalkan tertuama di wilayah maritim, namun pada saat ini masalah muncul karena banyaknya kapal dan jasa transportasi kapal yang menjadi mata pencaharian masyarakat maritim. Dengan begitu perbandingan antara kapal dengan kapal sangat meningkat, tertutama bisa disimpulkan dari banyaknya penumpang dan grafik penumpang kapal.. Dimasa sekarang kepuasan penumpang sangat diutamakan, terutama pada fasilitas yang mendukung seperti kursi yang nyaman, pendingin udara yang kondunsif, dan pelayanan yang baik. Namun metode penelitian yan digunakan pada inovasi ini adalah metode observasi yang mencakup pada pengambilan data pada pengujian pengguna dan pengalaman pengguna pada tahapnya.

Dengan latar belakang tersebut maka di usulkan sebuah inovasi teknologi berbasiskan mikrokontroller arduino uno yang dinamakan Form Kapalku.
Form Kapalku menjadi salah satu inovasi yang menerapkan pendataan kepuasan penumpang berbasis sistem informasi yang cara kerjanya adalah menekan tombol pilihan sesuai warna yang disediakan yaitu merah, kuning, dan hijau di masing-masing kursi penumpang. Data yang masuk akan di hitung sesuai dengan seberpaa banyak penumpang menekan tombol tersebut. Merah artinya tidak puas, hijau artinya puas, dan kuning artinya sangat puas. Dengan begitu, data yang didapatkan melalui kepekaan tombol akan dikirim melalui Bluetooth ke android. Selanjutnya data yang tertera di android akan tampil pada monitor yang dapat diakses melalui google form. Hasil dari penelitian ini dapat dilihat dari grafik data google form yang merupakan transisi data android melalui kepekaan tombol, sehingga dapat dengan mudah mengetahui tingkat kepuasan pelayanan pada kapal sesuai dengan kiteria dan peningkatan mutu kualitas kapal tersebut.

Proses penelitian dimulai dengan pendekatan secara sosial dengan melakukan aktivitas bersama calon pengguna inovasi, yang di integrasikan dengan pendekatan dengan design thinking untuk dapat menghasilkan inovasi berbasis teknologi yang bermanfaat bagi calon pengguna. Setelah mendapatkan solusi utama, maka akan dilanjutkan dengan pembuatan purwarupa sederhana yang akan dipergunakan untuk uji fungsi dan manfaat bersama calon pengguna. Dari hasil pengujian bersama calon pengguna, didapatkan hasil memuaskan dari segi kemudahan menggunakan teknologi, manfaat inovasi dan fungsi pada purwarupa.

\section{Penelitian terdahulu}

Aplikasi android pada tlepon seluler menjadi primadona saat ini, hal ini dilatar belakangi dengan penggunaan memori yang kecil ketika dioperasikan. Pada penelitian untuk mendapatkan informasi mengenai kepuasan pelanggan pada PDAM Tirta Khatulistiwa Kota Pontianak, dipergunakan sistem operasi android v4.1 (Jelly Bean) hingga android v5.1 (Lollipop). Pada komputer dirancang sebuah halaman yang terdiri dari login dan rekapitulasi. Sistem yang di 
integrasikan dengan MySQL,XAMPP dan Browser (Zoraya, Yulianti, dan Priyanto, 2016).

Kuesioner diperlukan untuk mengetahui tanggapan pelanggan dari pertanyaan yang diberikan. Dengan informasi yang didapatkan maka akan dilakukan tindakan lanjutan untuk meningkatkan pelayanana terhadap pelanggan dan kinerja secara internal .Dengan latar belakang tersebut, PT. PLN (Persero) Rayon Tegal Timur mengembangkan sebuah sistem kuesioner online yang dinamanakan E-Kuesioner Kepuasan Pelanggan (EKUPEL). Menggunakan teknologi PHP, XAMPP yang berbasis Web dan database MySQL.

\section{METODE PELAKSANAAN}

Desainer memainkan peran strategis dalam inovasi dan proses transisi menuju masyarakat yang berkelanjutan. Desainer bertindak di semua lapisan masyarakat dan membutuhkan bantuan untuk menemukan jalan melalui sistem inovasi yang semakin saling terkait (Joore dan Brezet, 2015), dengan latar belakang tersebut kemampuan mendesain dan kreativitas menjadi keterampilan yang sangat dicari dalam industri terkemuka di seluruh dunia, perusahaan besar mengembangkan "Chief Design Officer" untuk terlibat dengan diskusi strategis dan sebagai pendorong ekonomi perusahaan, oleh sebab itu diperlukan menanamkan "kreativitas" ke dalam pendidikan tingkat sekolah menengah dan universitas untuk mendorong inovasi dan pengembangan tingkat selanjutnya (Collins, 2015)

Selama siklus proses perancangan rekayasa, rekayasawan diharapkan untuk sepenuhnya memahami kebutuhan pelanggan walaupun menghadapi tantangan berupa geografis, jadwal proyek yang sempit, atau anggaran yang pendek. Dengan Design Thinking maka pemahaman kebutuhan pelanggan dilakukan dengan mempertimbangkan apa yang layak secara teknis dan ekonomis nantinya (Pereira dan Russo, 2018). Proses Desain Rekayasa adalah merupakan sebuah proses didalam mendesain dengan berpusat kepada pengguna. dimulai dengan etnografi hingga menghasilkan sebuah purwarupa yang merupakan sebuah konsep solusi yang sesuai dengan kebutuhan di masyarakat.

Penelitian dimulai dengan pendekatan Design Thinking yang diperkenalkan oleh Stanford Design School, yaitu memulai proses perancangan dengan social research yang di integrasikan dengan design thinking untuk dapat menghasilkan inovasi berbasis teknologi yang bermanfaat bagi masyarakat setempat. Setelah mendapatkan solusi utama, maka akan dilanjutkan dengan pembuatan sederhana yang akan dipergunakan untuk uji fungsi dan manfaat bersama calon pengguna, sila lihat Gambar 1.

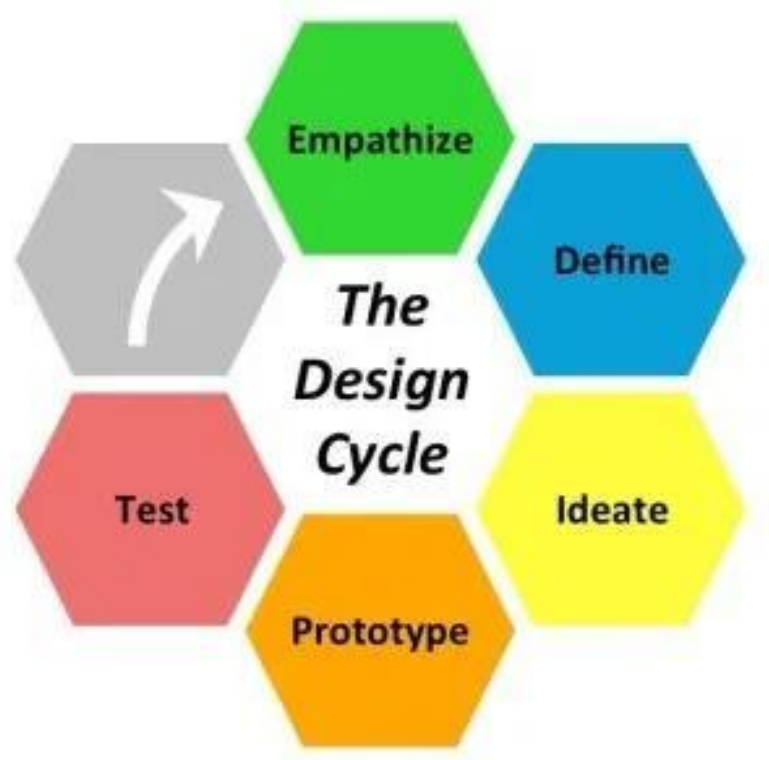

Gambar 1. Thinking About Design - A Framework for Tackling Wicked Problems (https://blog.convergeforimpact.com/thinking-about-design/) 
Proses ini memiliki 5 tahapan, pada tahapan awal dimulai dengan empati sebagai modal dasar dalam pelaksanaan observasi secara luas di masyarakat untuk mendapatkan permasalahanpermasalahan, dalam tahapan ini peneliti berusaha untuk mampu mengalami emosi dan mengetahui apa yang dipikirkan oleh calon pengguna. Tahapan kedua adalah proses pengerucutan dengan melakukan pemilihan permasalahan utama, tahapan ketiga adalah mengembangkan ide-ide sebagai solusi terhadap permasalahan utama untuk mendapatkan solusi utama sehingga dapat dilanjutkan ke tahapan pembuatan purwarupa dengan memperhatikan bahwa purwarupa yang dihasilkan sederhana dan mudah dirubah. Tahapan terahir adalah pengujian, bertujuan untuk mengetahui kinerja dari purwarupa dan mendapatkan masukan untuk perbaikan inovasi apabila diperlukan nantinya.

Lokasi penelitian dilakukan di Pelabuhan Sri Bintan Pura Tanjungpinang Kota, Kota Tanjung Pinang, Kepulauan Riau, lihat Gambar 2.

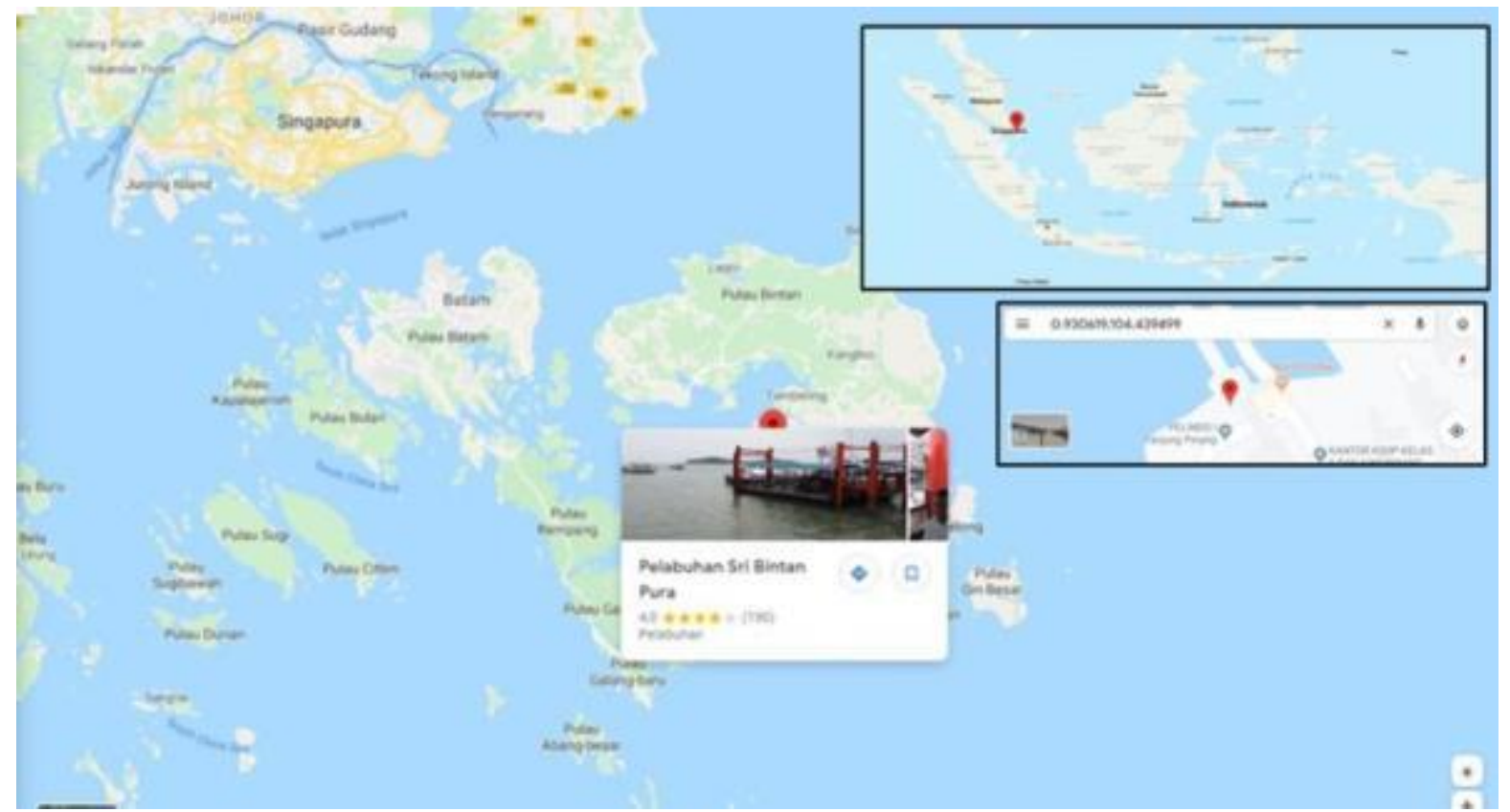

Gambar 2. Lokasi Penelitian di Pelabuhan Sri Bintan Pura Tanjungpinang Kota, Kota Tanjung Pinang, Kepulauan Riau (https://maps.app.goo.gl/bFe4SAHDxxN4xJA96)

\section{Proses Etnografi}

Salah satu cara observasi untuk memperoleh data yang dapat diandalkan tentang kebutuhan dan karakteristik pengguna masa depan adalah etnografi (Forsythe, 1995). Etnografi adalah metode observasi yang telah digunakan secara tradisional dalam antropologi, namun semakin menarik untuk diterapkan dalam riset konsumen, baik dalam bidang akademis maupun industri (Valentin dan Gomez-Corona, 2018). Etnografi juga merupakan metode pendekatan penelitian secara kualitatif yang digunakan untuk belajar tentang orang dan budaya (Ottrey, Jong dan Porter, 2018). Peneliti berpartisipasi aktif mengikuti aktivitas bersama kelompok yang sedang diteliti dan kelompok yang sedang diteliti mengetahui mengenai penelitian sehingga peneliti dan kelompok yang diteliti akan lebih lebih dekat dan terbuka, dimana pada ahirnya timbul saling percayaan, pada ahirnya akan memberikan informasi yang lebih dalam (Wagner, Kawulich dan Garner, 2012).

Langkah awal dari Proses Desain Rekayasa, yang merupakan aktivitas pegamatan atau observasi secara langsung ke masyarakat di suatu daerah untuk mendapatkan data yang akurat sehingga mampu menghasilkan sebuah solusi yang tepat.

Pada Gambar 3 menampilkan keadaaan di Pelabuhan Sri Bintan Pura Tanjungpinang untuk mendapatkan data-data yang di perlukan. Pada Gambar 4 memperlihatkan peneliti melakukan proses pengumpulan informasi di Pelabuhan Sri Bintan Pura Tanjungpinang 


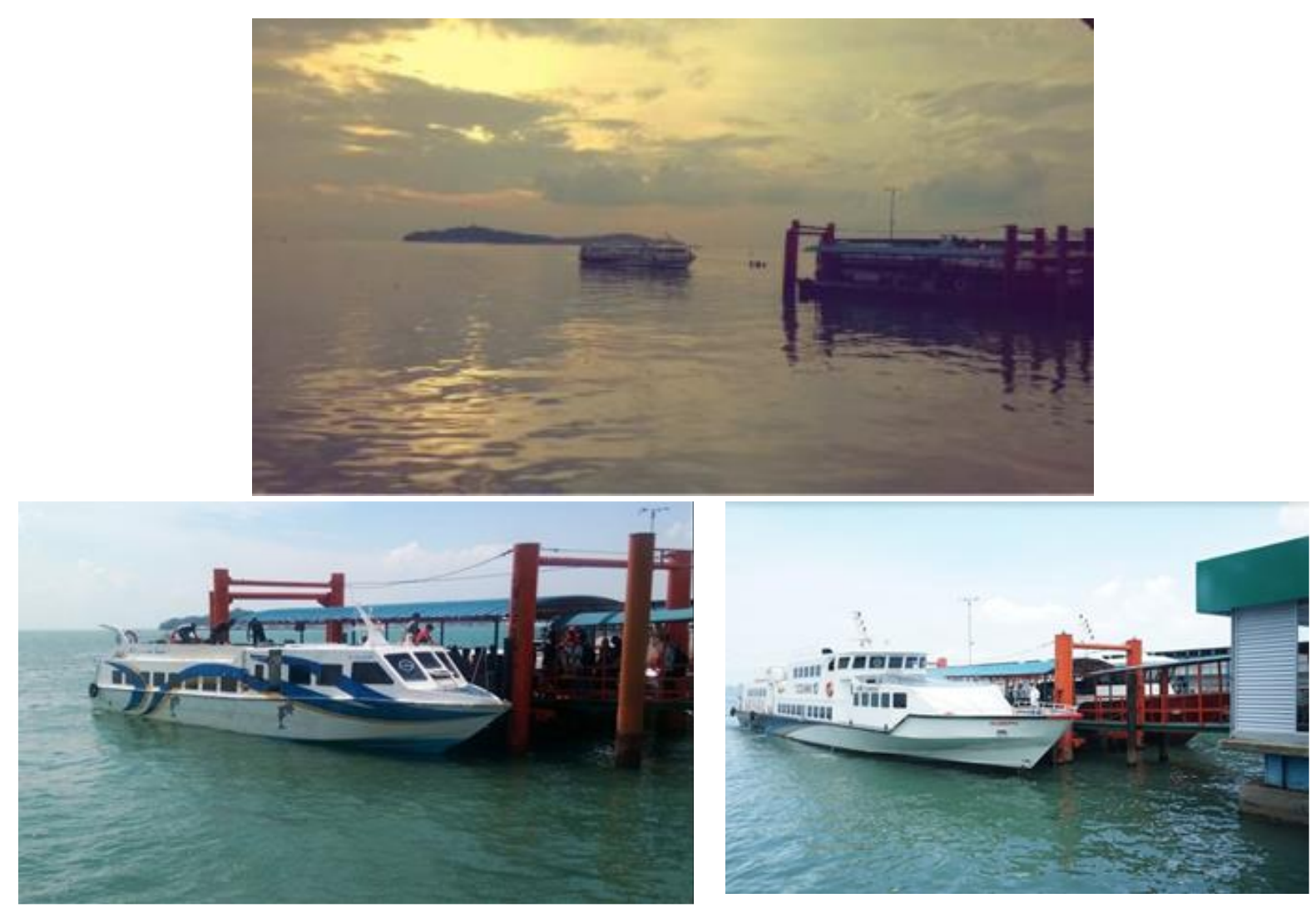

Gambar 3. Suasana di Pelabuhan Sri Bintan Pura Tanjungpinang
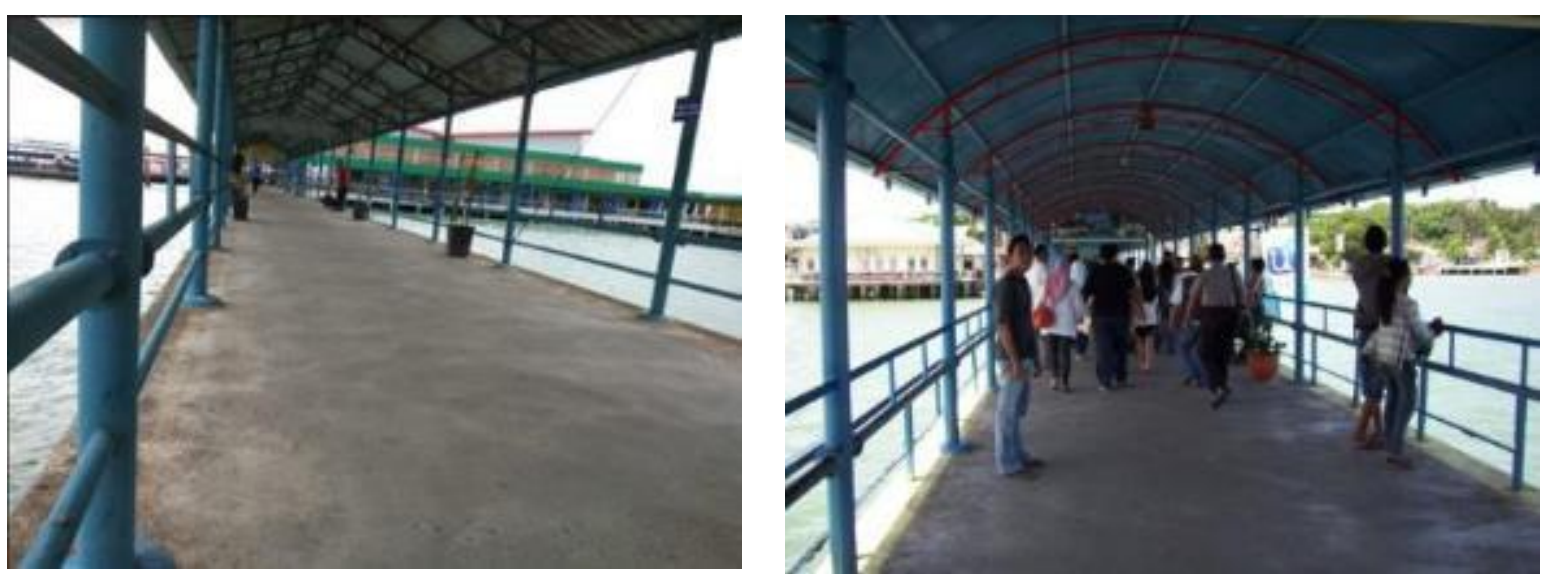

Gambar 4. Mengumpulkan Informasi Mengenai Permasalahan Di Pelabuhan Sri Bintan Pura Tanjungpinang

\section{KARYA UTAMA}

Form Kapalku menjadi salah satu inovasi yang menerapkan pendataan kepuasan penumpang berbasis sistem informasi yang cara kerjanya adalah menekan saklarl pilihan sesuai warna yang disediakan yaitu merah, kuning, dan hijau di masing-masing kursi penumpang. Data yang masuk akan di hitung sesuai dengan seberpaa banyak penumpang menekan tombol tersebut. Merah artinya tidak puas, hijau artinya puas, dan kuning artinya sangat puas. Dengan begitu, data yang didapatkan melalui kepekaan tombol akan dikirim melalui bluetooth ke android. Sistem menggunakan mikrokontroler arduino uno. Sila lihat Gambar 5. 
Adapun komponen yang diperlukan untuk pembuatan purwarupa dengan estimasi harga

adalah sila lihat pada Tabel 1.

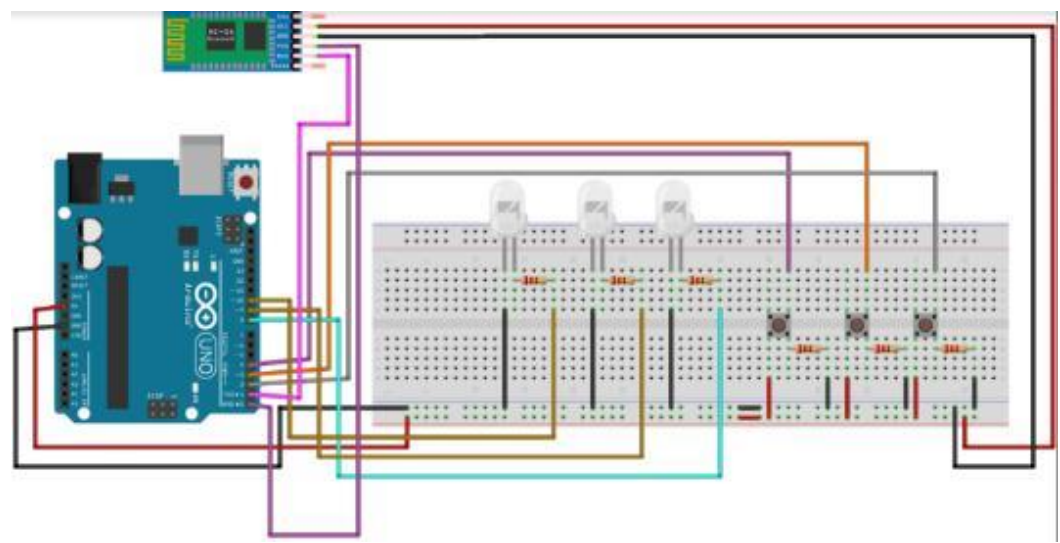

Gambar 5. Rangkaian Arduino dari Form Kapalku Guna Pendataan Kepuasan Penumpang Kapal Ferry Dari Pelabuhan Tanjungpinang

Tabel 1. Estimasi anggaran untuk perakitan Purwarupa (Bukalapak, diakses 30 Januari 2020)

\begin{tabular}{rlrrr}
\hline No. & Barang & Jumlah & $\begin{array}{c}\text { Harga } \\
\text { Satuan (Rp) }\end{array}$ & \multicolumn{1}{c}{$\begin{array}{c}\text { Harga } \\
\text { Total (Rp) }\end{array}$} \\
\hline 1 & Arduino Uno & 1 & 85000 & 85000 \\
\hline 2 & Bluetooth Modul & 1 & 40000 & 40000 \\
\hline 3 & Project board & 1 & 25000 & 25000 \\
\hline 4 & Kabel Jumper & 20 & 1000 & 20000 \\
\hline 5 & Saklar Tekan & 3 & 1500 & 4500 \\
\hline 6 & Resistor & 4 & 500 & 2000 \\
\hline 7 & LED & 4 & 500 & 2000 \\
\hline & Jumlah & & & 178500 \\
\hline
\end{tabular}

Arduino Uno R3 adalah merupakan sebuah mikrokontroller, dimana mikrokontroler tersebut akan memproses input yang diberikan melalui bahasa pemograman open source sehingga akan menghasilkan output. Cukup hubungkan Arduino dengan kabel USB ke PC atau Mac/Linux anda, jalankan software Arduino sudah bisa untuk memprogram chip ATmega328. Sila lihat Gambar 6.

Breadboard adalah dasar konstruksi sebuah sirkuit elektronik dan merupakan purwarupa dari suatu rangkaian elektronik. Breadboard banyak digunakan untuk merangkai komponen, karena dengan menggunakan breadboard, pembuatan purwarupa tidak memerlukan proses menyolder (langsung tancap ). Karena sifatnya yang solderless alias tidak memerlukan solder sehingga dapat digunakan kembali dan dengan demikian sangat cocok digunakan pada tahapan proses pembuatan purwarupa serta membantu dalam berkreasi dalam desain sirkuit elektronika., sila lihat Gambar 7. 


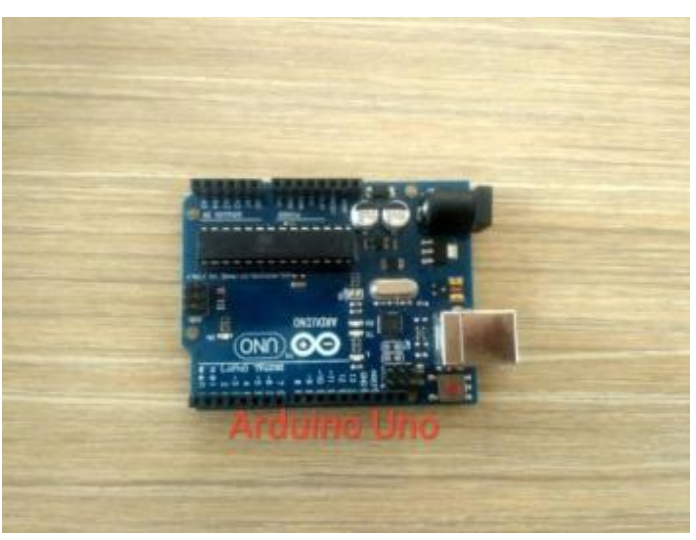

Gambar 6. Arduino Uno

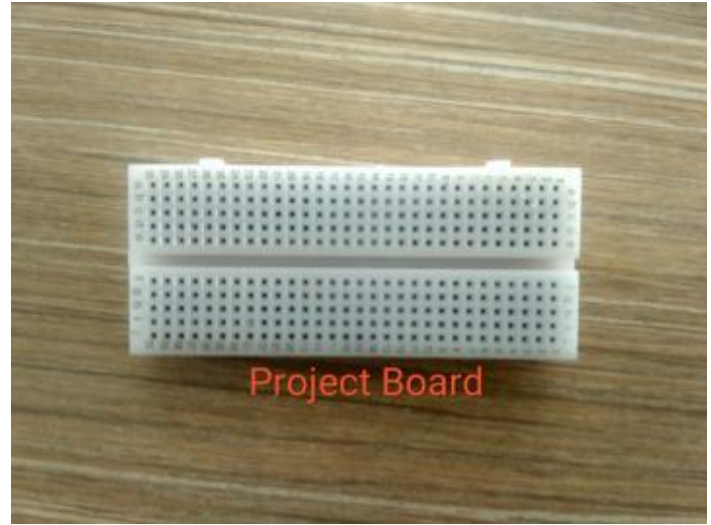

Gambar 7. BreadBoard

Kabel jumper adalah kabel yang di dipasangkan dengan mudah ke dalam berbagai pergunakan untuk menghubungkan satu perangkat elektronika. Berbeda dengan Lampu komponen dengan komponen lain ataupun Pijar, LED tidak memerlukan pembakaran menghubungkan jalur rangkaian yang terputus filamen sehingga tidak menimbulkan panas pada breadboard, sila lihat Gambar 8. LED dalam menghasilkan cahaya. Oleh karena itu, adalah sebuah komponen elektronika yang akan LED dengan bentuk yang kecil telah banyak menampilkan cahaya apabila diberikan tegangan. Adapun bentuk LED mirip dengan sebuah dipergunakan sebagai lampu penerang untuk mengganti lampu tabung. Sila lihat Gambar 9.

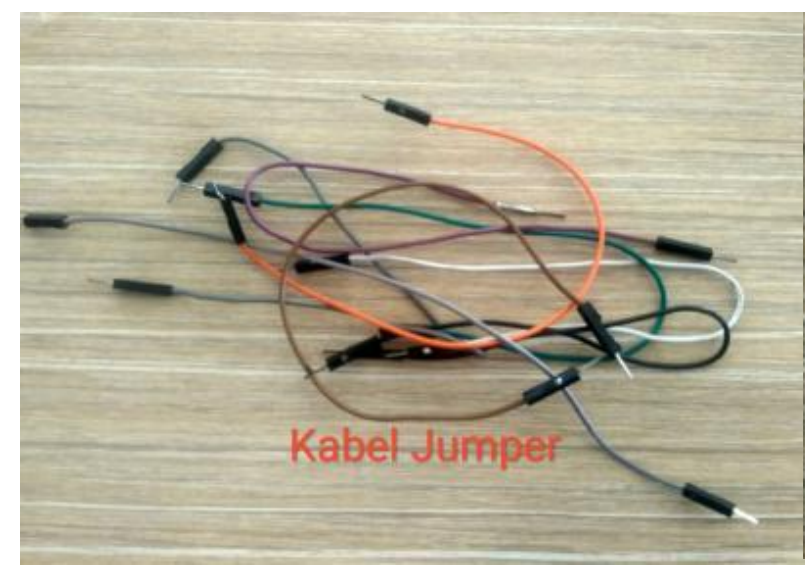

Gambar 8. Kabel Jumper

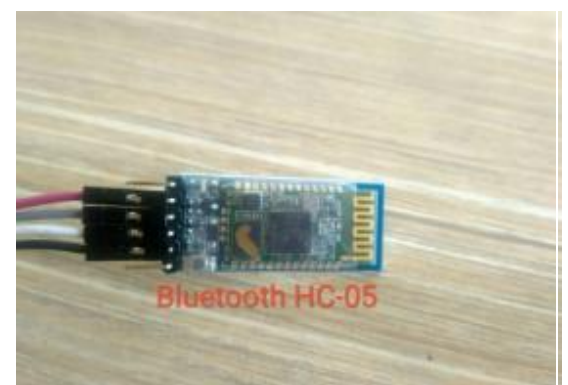

Gambar 10. Bluetooth Modul

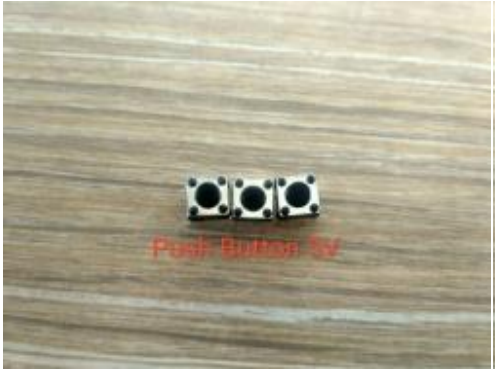

Gambar 11 . Saklar Tombol Tekan

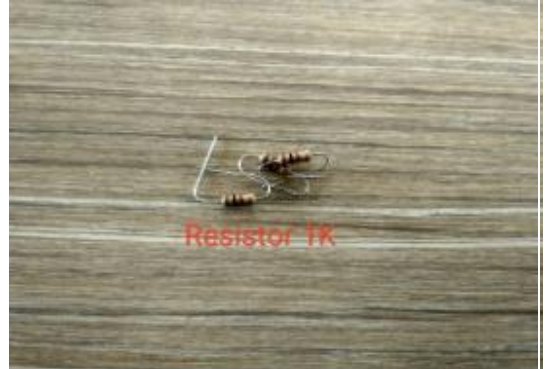

Gambar 12. Resistor
Gambar 9 . LED 
Bluetooth adalah sebuah alat yang dipergunakan untuk menghubungkan sebuah perangkat dengan perangkat lainnya tanpa kabel.. Sila lihat Gambar 10. Saklar tombol tekan adalah perangkat / saklar sederhana yang berfungsi untuk menghubungkan atau memutuskan aliran arus listrik dengan sistem kerja tekan unlock (tidak mengunci). Sistem kerja unlock disini berarti saklar akan bekerja sebagai device penghubung atau pemutus aliran arus listrik saat tombol ditekan, dan saat tombol tidak ditekan (dilepas), maka saklar akan kembali pada kondisi normal,. Sila lihat Gambar 11. Resistor adalah komponen Elektronika Pasif yang memiliki nilai resistansi atau hambatan tertentu yang berfungsi untuk membatasi dan mengatur arus listrik dalam suatu rangkaian Elektronika. fungsi-fungsi Resistor di dalam rangkaian elektronika memiliki fungsi pembatas dan pengatur arus listrik, serta pembagi dan penurun tegangan listrik. Sila lihat Gambar 12.

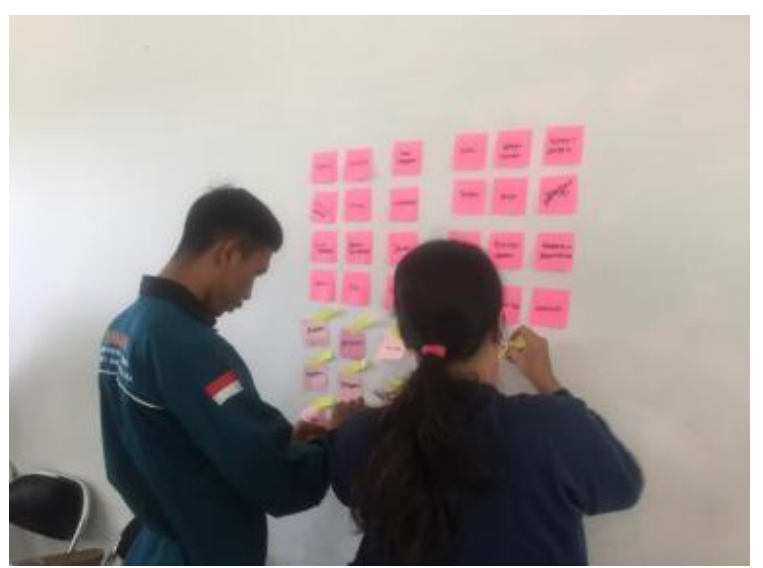

Gambar 13. Proses pengumpulan masalah

Permasalahan utama adalah satu permasalahan yang akan dijadikan landasan untuk langkah penentuan solusi, dalam tahapan ini akan dilakukan proses pengerucutan masalah, dimulai dengan pengelompokan masalah dan selanjutnya di pilih satu masalah saja, lihat Gambar 14. Proses diskusi bersama sesama anggota kelompok dengan saling memberikan penjelasan terhadap masalah yang akan dijadikan masalah utama diperlukan untuk mendapatkan informasi-informasi yang belum dapat

\section{ULASAN KARYA}

Tahapan selanjutnya adalah curahan gagasan permasalahan yang ditemukan di sekolah dari hasil observasi, dimana semua permasalahan yang ditemukan akan di dokumentasikan. Proses ini adalah merupakan tahapan yang penting, karena sangat diharapkan bahwa solusi yang akan dihasilkan adalah merupakan solusi yang dibutuhkan, bukan solusi yang diminta oleh calon pengguna. Pola penyampaian gagasan secara bebas akan sangat diperlukan untuk memotivasi peneliti untuk mampu berpikir inovatif dan kreatif. Curahan gagasan yang bersifat luas adalah merupakan pondasi bagi rekayasawan untuk mampu menghasilkan sebuah inovasi yang berbasiskan teknologi. Hal ini sering dipahami dengan $\mathrm{T}$ concept, dimaksudkan bahwa inovasi yang dihasilkan memiliki pengaruh yang luas dan mendalam. Pada Gambar 13 dapat dilihat proses pengumpulan masalah-masalah yang sangat berkaitan dengan kejadian di sekolah selama melakukan observasi dan wawancara

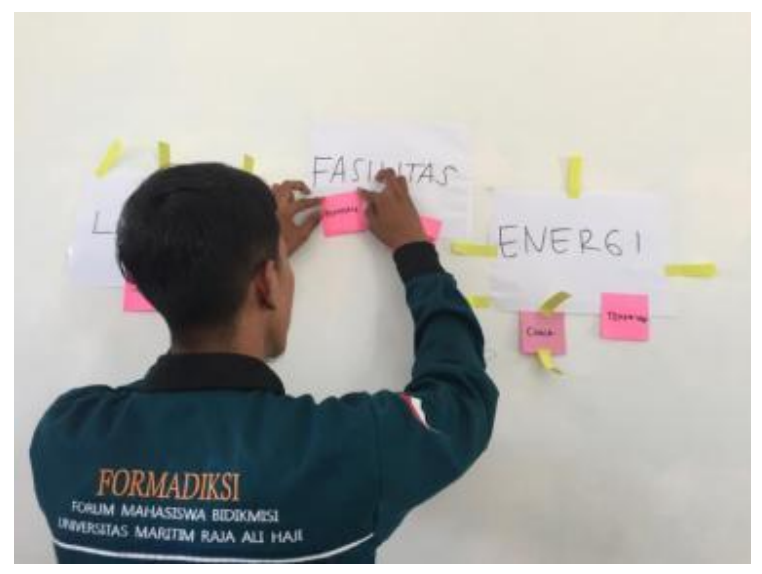

Gambar 14. Proses pengerucutan masalah untuk mendapatkan masalah utama

disampaikan pada tahapan sebelumnya. Adapun permasalahan utama dari penelitian ini adalah cahaya matahari yang masuk ke ruangan kelas.

\section{Purwarupa}

Tahapan curahan gagasan solusi dari masalah utama dilakukan setelah mendapatkan permasalahan utama. Dalam tahapan ini akan disampaikan beberapa konsep solusi bersama anggota peneliti lainnya. Dengan mempergunakan alat tulis yang dituangkan 
kedalam sketsa dapat dilihat pada dilihat pada

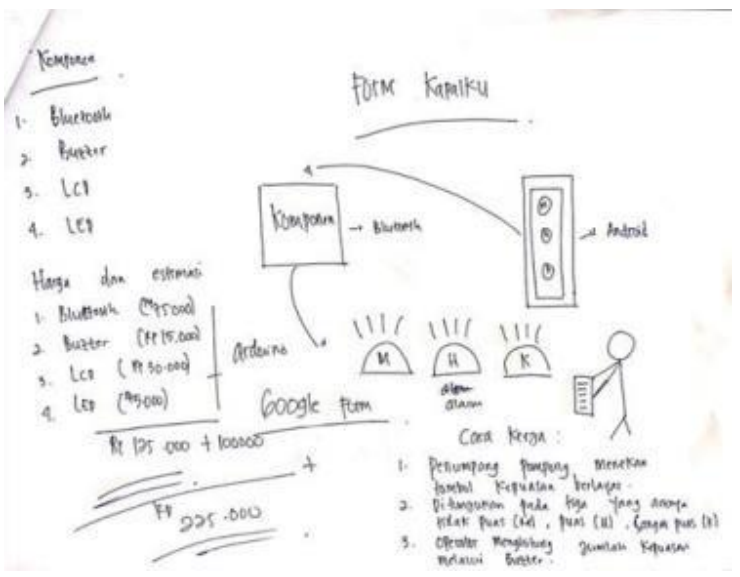

Gambar 15

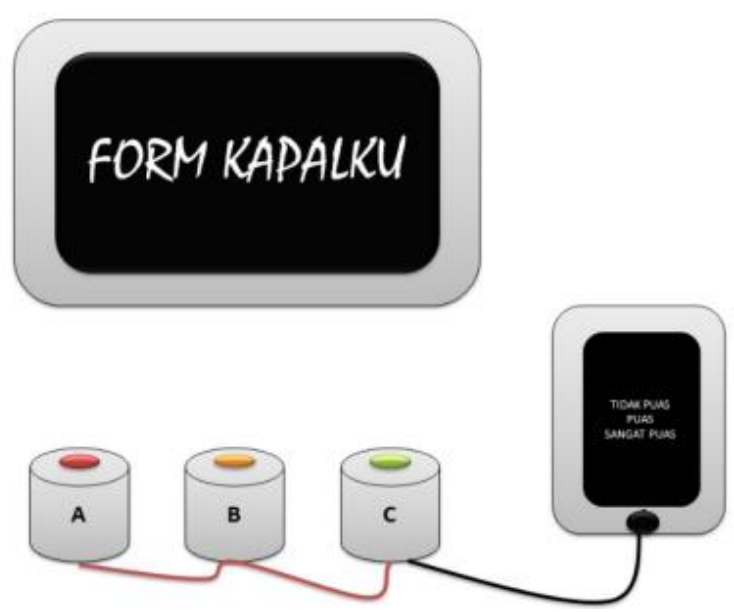

Gambar 15. Konsep Solusi Bersama Anggota Peneliti Lainnya. Dengan Mempergunakan Alat Tulis Yang Dituangkan Kedalam Sketsa

Sedangkan pada Gambar 16 menampilkan konsep solusi utama berupa perangkat tirai otomatis yang digambar menggunakan perangkat lunak desain Autodesk Inventor. Tahapan yang sudah mulai memerlukan pembiayaan adalah tahapan pembuatan purwarupa. Oleh sebab itu pada Proses Desain Rekayasa ini, menekankan untuk mampu menghasilkan purwarupa sederhana yang ekonomis dan fleksible, dengan

maksud bahwa perubahan rancangan dapat dilakukan dengan mudah dan tidak akan memerlukan pembiayaan yang besar. Purwarupa dalam tahapan ini lebih dikenal dengan istilah low resolution prototype (Nusyirwan, 2017). Dapat dilihat pada Gambar 17 adalah integrasi purwarupa purwarupa dengan bahan yang ekonomis dan fleksible.

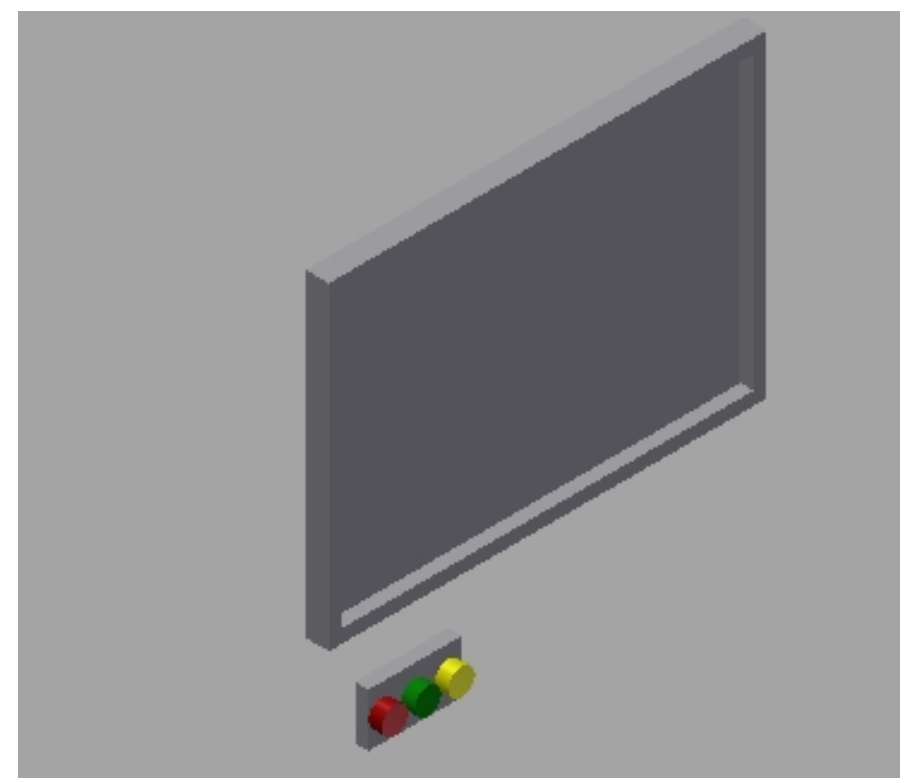

Gambar 16. Purwarupa menggunakan perangkat lunak Autodesk Inventor
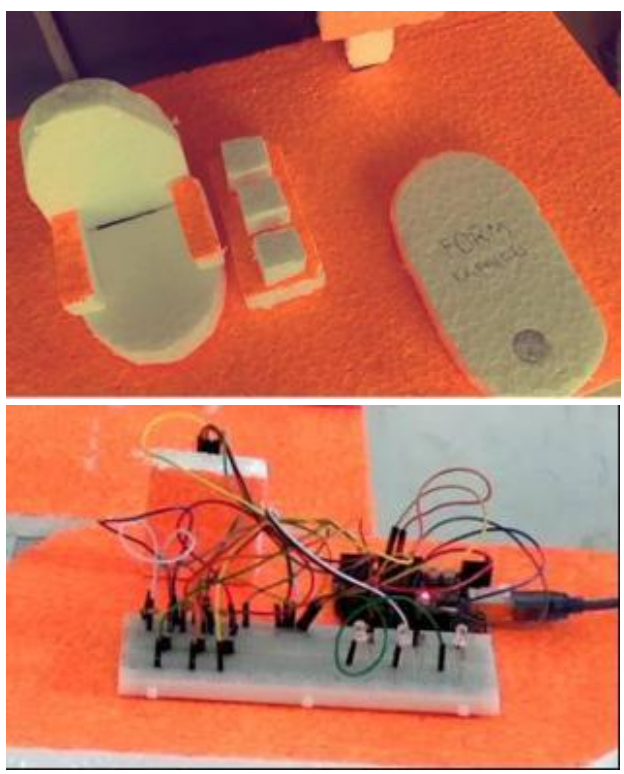

Gambar 17. Purwarupa Sederhana

\section{Pengujian Kegunaan}

Pengujian kegunaan adalah proses evaluasi terhadap inovasi yang dirancang dengan berbasis pengguna. Pada tahapan ini pengguna akan berpartisipasi dan berinteraksi secara langsung dengan purwarupa sederhana yang dihasilkan 
dari proses sebelumnya. Pengguna akan diminta untuk melakukan tugas tertentu atau hanya menjelajahinya secara bebas, sementara perilaku pengguna diamati dan dicatat untuk mengidentifikasi kelemahan desain yang menyebabkan kesalahan atau kesulitan pengguna.
Selama pengamatan ini, Setelah kelemahan desain telah diidentifikasi, rekomendasi desain diusulkan untuk meningkatkan kualitas ergonomis produk (Bastien, 2010). Pada Gambar 18 menampilkan uji coba kegunaan untuk mengetahui kerja dan kinerja dari program.
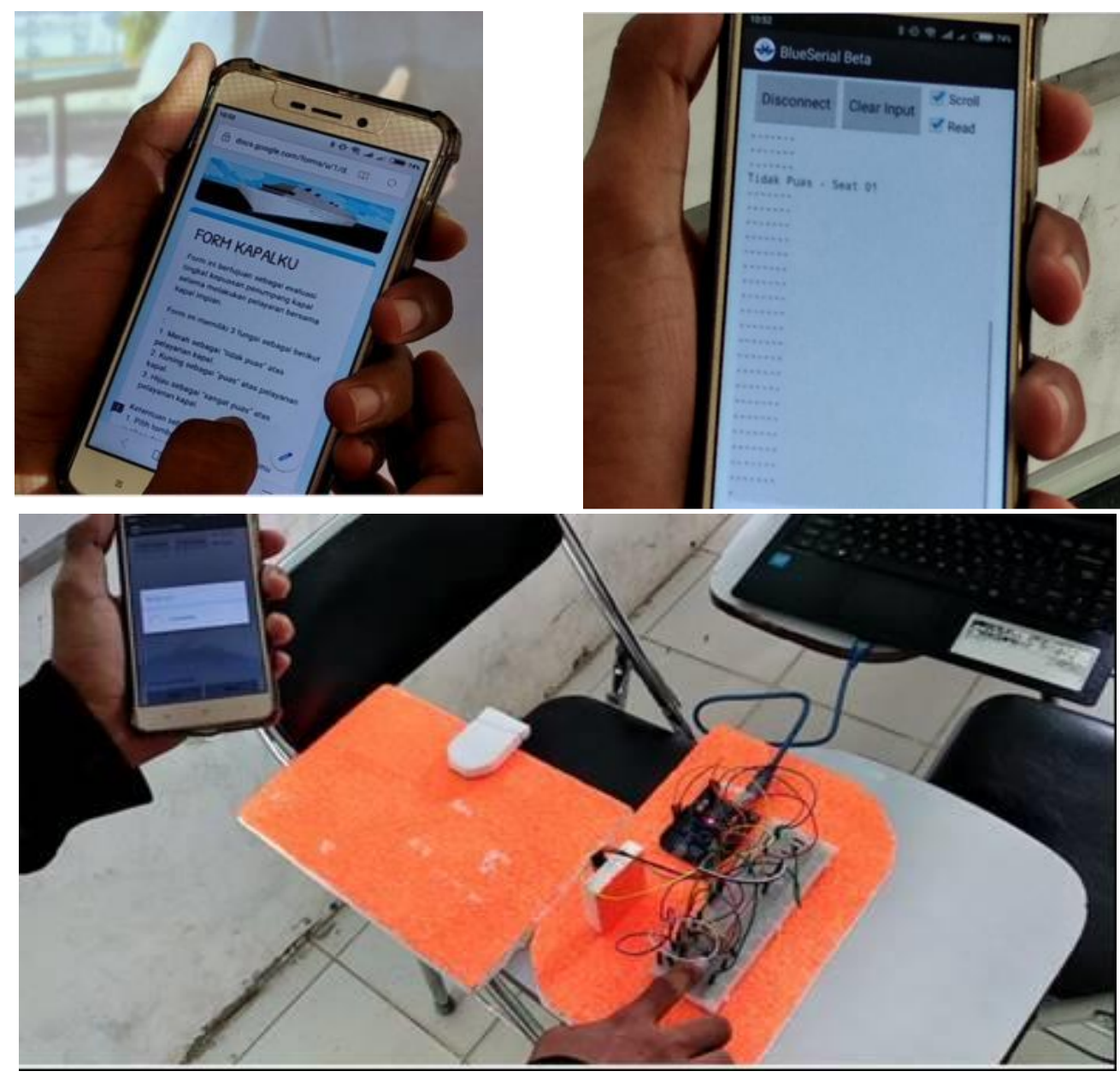

Gambar 18. Pengujian kegunaan purwarupa.

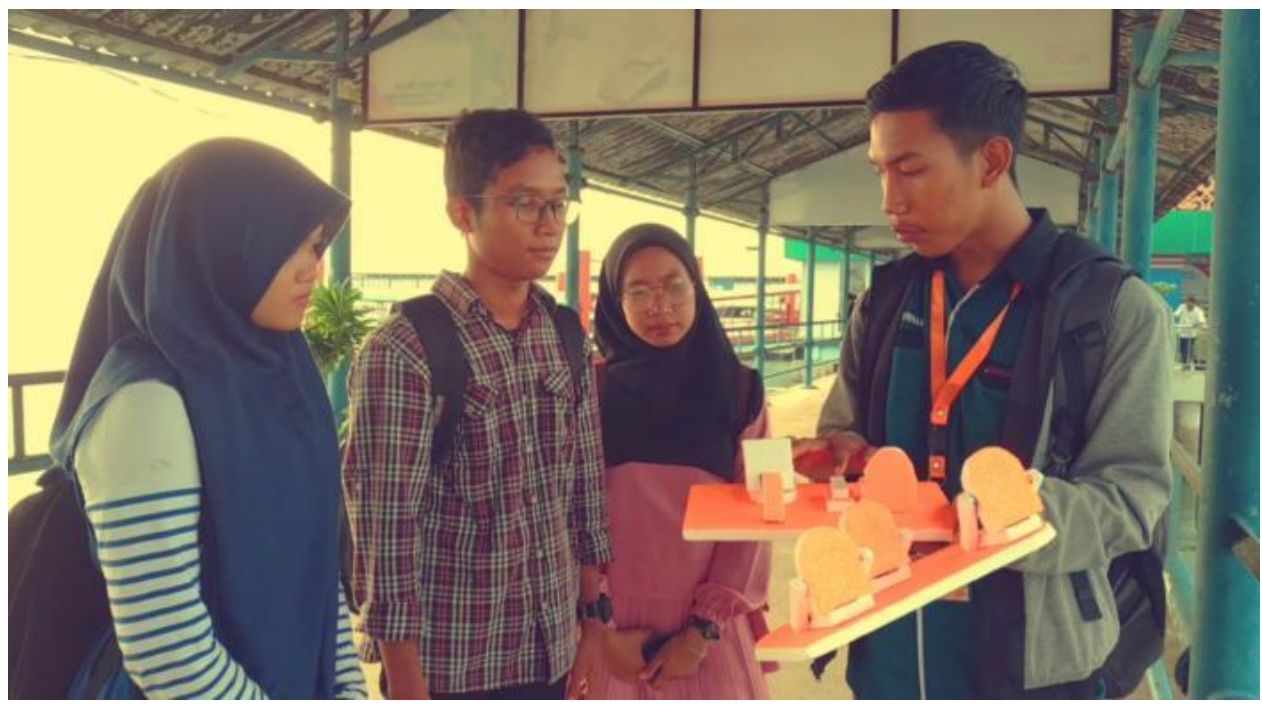

Gambar 19. Pengujian kegunaan bersama caon pengguna 
Pengalaman pengguna akan memperluas pandangan tentang interaksi produk dengan pengguna dari aspek emosional. Adapun motivasi dari proses pengalaman pengguna adalah untuk mengembangkan pengalaman dan emosi positif. Oleh karena itu, produk harus memenuhi kebutuhan psikologis dan motif pelanggan (von Saucken, Lachner, dan Lindemann, 2014). Pada
Gambar 18 menampilkan pengujian kegunaan purwarupa.bersama calon pengguna.

\section{Program pada Arduino}

Dibawah ini adalah program yang ditulis pada Arduino untuk dapat menghasilkan luaran sesuai yang di inginkan pada form kapalku. Sila lihat pada Gambar 20.

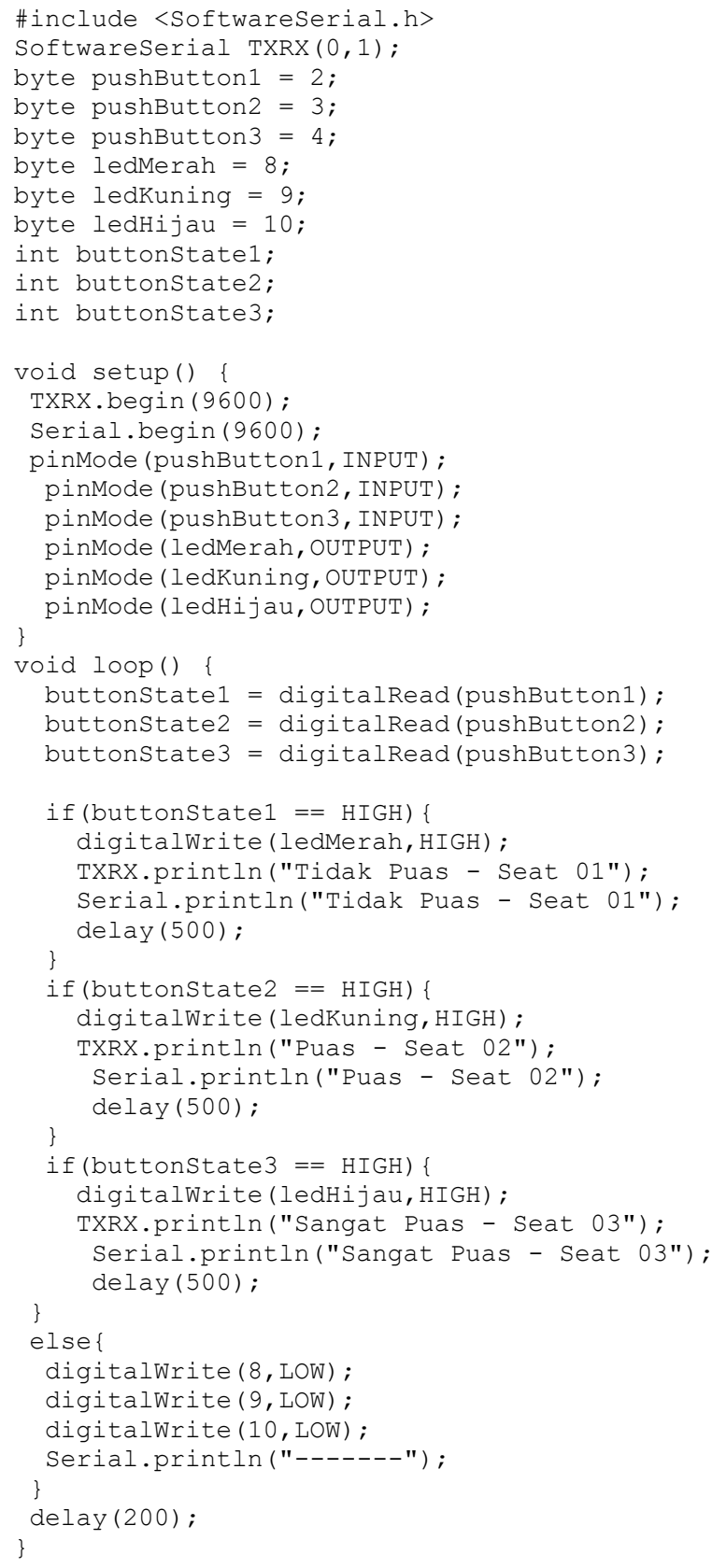

Gambar 20. Program yang ditulis pada Arduino 


\section{DAMPAK DAN MANFAAT KEGIATAN}

Inovator yang berbasiskan teknologi sangat sadar bahwa kesuksesan hasil inovasi tidak hanya dilihat dari manfaat dari produk yang akan dihasilkan namun juga perlu memperhatikan faktor pengalaman pengguna., sehingga pengembangan inovasi teknologi tidak lagi hanya tentang mengimplementasikan fitur dan menguji kegunaannya, tetapi juga tentang mendesain produk yang menyenangkan dan mendukung kebutuhan dan nilai-nilai dasar manusia. Dengan demikian, pengalaman pengguna dalam tahapan Proses Desain Rekayasa harus menjadi perhatian utama pengembangan produk (Johnson, Clegg dan Ravden, 1989).

Tabel 2. Hasil Interview dari calon pengguna

\begin{tabular}{|c|c|c|c|c|c|c|c|c|c|}
\hline \multirow{3}{*}{ No. } & \multirow{3}{*}{ PERTANYAAN } & \multicolumn{4}{|c|}{ CALON PENGGUNA PERTAMA } & \multicolumn{4}{|c|}{ CALON PENGGUNA KEDUA } \\
\hline & & 4 & 3 & 2 & 1 & 4 & 3 & 2 & 1 \\
\hline & & $\begin{array}{l}\text { SANGAT } \\
\text { BAIK }\end{array}$ & BAIK & CUKUP & KURANG & $\begin{array}{l}\text { SANGAT } \\
\text { BAIK }\end{array}$ & BAIK & CUKUP & KURANG \\
\hline 1 & $\begin{array}{l}\text { PURWARUPA } \\
\text { INI MUDAH } \\
\text { DIGUNAKAN }\end{array}$ & & & & & & & & \\
\hline 2 & $\begin{array}{l}\text { INOVASI } \\
\text { MENARIK }\end{array}$ & & & & & & & & \\
\hline 3 & $\begin{array}{l}\text { INOVASI } \\
\text { BERGUNA } \\
\text { UNTUK } \\
\text { MASYARAKAT }\end{array}$ & & & & & & & & \\
\hline 4 & $\begin{array}{l}\text { INOVASI DAPAT } \\
\text { BERFUNGSI }\end{array}$ & & & & & & & & \\
\hline 5 & $\begin{array}{l}\text { SISTEM SUDAH } \\
\text { OPTIMAL }\end{array}$ & & & & & & & & \\
\hline
\end{tabular}

Pada Tabel 2 adalah hasil dari uji coba bersama pengguna untuk mendapatkan informasi terkait fungsi dan manfaat inovasi tirai otomatis untuk sekolah dasar. Dapat dilihat bahwa purwarupa yang dihasilkan sudah dapat memenuhi kretria dasar sebuah inovasi, yaitu mudah dimngerti, sederhana dan dapat diaplikasikan di lingkungan yang menjadi objek penelitian. Dari hasil pengujian tersebut, pengguna berharap bahwa purwarupa untuk dapat lebih memiliki fungsi tambahan lainnya.Tentunya dengan biaya yang terjangkau untuk dapat segera diaplikasikan di sekolah dasar. ,

\section{KESIMPULAN DAN SARAN}

\section{Kesimpulan}

Kepuasan penumpang menjadi salah satu peran penting didalam perusahaan maupun jasa transportasi yang berdominan kepada inovasi sosial. Wilayah maritim adalah wilayah yang sebagaian besarnya adalah perairan. Pada wilayah maritim Provinsi Kepulauan Riau, jasa transportasi mengarah kepada laut. Kapal laut menjadi salah satu bentuk kecanggihan transportasi dari dahulu hingga sekarang. Kapal juga menjadi salah satu transportasi yang dapat diandalkan. Salah satu faktor yang mampu meningkatkan penggunaan jasa transportasi kapal adalah kenyamanan penumpang. Dengan mengguanakan inovasi Form Kapalku, pemilik kapal dapat langsung melakukan monitoring terhadap palayanan yang di berikan dengan menggunakan teknologi berbasiskan internet. Pengguna kapal dapat memberikan tanggapan secara langsung di tempat yang sudah disediakan.

\section{Saran}

Penggunaan teknologi internet telah menjadi kebutuhan, dari hasil ujicoba dengan penggunak teknologi maka dapat ditemukan antusias pengguna didalam menggunakan 
teknologi form kapalku. Kedepannya diharapkan teknologi ini dapat disebarluaskan kepada setiap kapal untuk dapat dilakukan monitoring secara keseluruhan oleh otoritas pelabuhan laut yang selanjutnya menjadi masukan untuk evaluasi.

\section{UCAPAN TERIMAKASIH}

Terima kasih kepada civitas akademika di jurusan teknik elektro Universitas Maritim Raja Ali Haji (UMRAH) dan Redaksi Jurnal Terapan Abdimas.

\section{DAFTAR PUSTAKA}

Afriliana, I., Munadia, H., dan Hasta, I., D. (2018). EKUPEL: E-Kuesioner Kepuasan Pelanggan Pada PT. PLN (Persero) Rayon Tegal Timur, urnal ICT : Information Communication \& Technology, Vol. 17, No.01, 28-33

Collins, P., K., (2015), Building a Local Design and Entrepreneurship Ecosystem, Procedia Technology, 258:262

Forsythe,D., E., (1995). Using Ethnography In The Design Of An Explanation System, Expert Systems with Applications, 8(4):403-417

Johnson, G., I., Clegg, C., W., and Ravden, S., J., (1989). Towards Practical User Experience Evaluation Methods, Applied Ergonomics, 20(4):255-260

Joore, P., and Brezet, H., (2015). A Multilevel Design Model: The Mutual Relationship Between Product-Service System Development And Societal Change Processes, Journal of Cleaner Production, 97:92-105

Kurniadi, D., dan Islami, A., F. (2018). Perancangan Aplikasi Survei Kepuasan Mahasiswa Berbasis Kuesioner Online, Jurnal Algoritma, Vol.15, N0. 02, 7-14

Nusyirwan, D., (2017). Engineering Design Process Engineering Student Centered
Experience Learning (ESCEL) di Jurusan Teknik Elektro Universitas Maritim Raja Ali Haji (UMRAH), Jurnal , 6(1):24-35

Ottrey, E., Jong,J., and Porter, J., (2018). Ethnography in Nutrition and Dietetics Research: A Systematic Review, Journal of the Academy of Nutrition and Dietetics, 118(10):1903-1942.e10

Pereira, J., C., and Russo, R. F.S.M., (2018). Design Thinking Integrated in Agile Software Development: A Systematic Literature Review, Procedia Computer Science, 138:(775-782)

Saputra, P., A. Dan Nugroho, A. (2017). Perancangan Dan Implementasi Survei Kepuasan Pengunjung Berbasis Web Di Perpustakaan Daerah Kota Salatiga, JUTI, Vol. 15, No.01, $63-71$

Valentin, D., and Gomez-Corona, C., (2018). Methods in Consumer Research, 1:103123

von Saucken, C., Lachner, F., and Lindemann, U., (2014). Principles for User Experience What We Can Learn from Bad Examples, International Conference on Kansei Engineering \& Emotion Research

Wagner, C., Kawulich, B., and Garner, M., (2012). "Collecting Data Through Observation", Doing Social Research: A global context, McGraw Hill

Zoraya, R., D, Yulianti, Priyanto, H. (2016) Rancang Bangun Aplikasi Kepuasan Pelanggan Terhadap Kualitas Pelayanan Pdam Tirta Khatulistiwa Kota Pontianak Dengan Metode Cut Off Point Berbasis Android, Jurnal Sistem dan Teknologi Informai, Vol 04, No. 01, 16-20 